\title{
Sprawozdanie z konferencji \\ Studenckiego Koła Naukowego Historii Kultury i Edukacji „Wykluczenie społeczne wczoraj i dziś"
}

Dnia 23 maja 2011 r. w Poznaniu na Wydziale Studiów Edukacyjnych Uniwersytetu im. Adama Mickiewicza odbyła się konferencja Studenckiego Koła Naukowego Historii Kultury i Edukacji. Podczas całodziennego spotkania zostało wygłoszonych 15 referatów omawiających temat odrzucenia społecznego. Warty podkreślenia jest fakt, że temat nie był traktowany intra, tylko interdyscyplinarnie. Głos zabierali przedstawiciele różnych gałęzi nauk humanistycznych: historycy wychowania, socjologowie, kulturoznawcy, pedagodzy specjalni, literaturoznawcy i historycy. Byli wśród nich goście z różnych ośrodków naukowych Polski, a mianowicie z Uniwersytetu Śląskiego, Warszawskiego czy Wrocławskiego. Na uwagę zasłużyły również prace przedstawione przez studentów różnych wydziałów Uniwersytetu im. A. Mickiewicza w Poznaniu.

Punktualnie o 10.00 konferencję w imieniu władz dziekańskich otworzyła prof. dr hab. Dorota Żołądź-Strzelczyk. W swym przemówieniu zwróciła uwagę na ponadczasowość problemu odrzucenia społecznego, jego wszechobecność w różnych grupach społeczno-kulturowych oraz kryteria jego definiowania. Prelegentka na podstawie traktowania nieślubnych dzieci i ich matek na przestrzeni od XV do XX w. zwróciła uwagę na fakt, że kryteria te ulegają nieustannym transformacjom i zmianom oraz zaznaczyła, jak podstawową i jednocześnie niezwykle istotną kwestią jest zrozumienie mechanizmów wpływających na te zmiany.

Następnie głos zabrał opiekun koła naukowego organizującego konferencję dr Krzysztof Ratajczak. Po omówieniu spraw organizacyjnych, w tym planów publikacji wystąpień w formie e-book’a - książki dostępnej w Internecie, rozpoczęła się robocza część konferencji. Spotkanie podzielone było na pięć części, w każdej z nich przedstawiano i omawiano trzy referaty. Poszczególne części oddzielone były przerwami pozwalającymi na pokrzepienie ciała i duszy: przygotowanym przez Wydział poczęstunkiem oraz kuluarowymi spotkaniami i dyskusjami.

\section{Część pierwsza - „Wykluczenie a przeszłość”}

Dr Krzysztof Ratajczak (UAM), „Społeczeństwo wykluczonych? O przyczynach wykluczenia społecznego w średniowieczu".

Pierwszą część konferencji, „Wykluczenie a przeszłość”, rozpoczęło wystąpienie dr. Krzysztofa Ratajczaka. W referacie prelegent skupił się na średniowieczu w aspekcie wpływów kościoła rzymskiego, zaznaczając jak wielki wpływ miała ta właśnie instytucja na kształtowanie się ,społeczeństwa wykluczonych”. W swojej prezentacji poruszył tematy, takie jak zasygnalizowany przez profesor Dorotę Żołądź-Strzelczyk - kwestię nieślubnych dzieci, rozdarcie społeczeństwa między sacrum - Kościół a profanum, problem 
z umiejscowieniem kobiet w społeczeństwie (ich przedmiotowość, w pewnym sensie przynależność do mężczyzny). Omówione zostały przypadki odrzucenia w odniesieniu do wszystkich grup społecznych, od problemu przynależności stanowej chłopów, przez kwestię wykluczenia Żydów, naznaczenia „heretyków”, pozbawiania czci rycerzy, do ekskomunikowania koronowanych głów. Konkluzją pracy dr. Krzysztofa Ratajczaka było stwierdzenie, że wykluczenie w średniowieczu mogło dotyczyć przeważającej części społeczeństwa.

Mgr Hanna Grzesiak (UAM), „Wykluczenie społeczne w starożytnym Izraelu”.

Drugim referatem przedstawionym na konferencji była praca mgr Hanny Grzesiak. Została tu omówiona kwestia mamzera (dziecka ze związku pozamałżeńskiego i/lub kazirodczego), wykastrowanych mężczyzn, cudzołożników, wdów, czy też osób z jakiegoś powodu „nieczystych”. Pani magister wytłumaczyła też kwestie odrzucenia społecznego na podstawie chorób, takich jak np. trąd, głuchota, niepełnosprawność intelektualna czy uprzywilejowanej pozycji osób starszych. Ważnym elementem pracy mgr Hanny Grzesiak było cytowanie źródeł historycznych w trakcie omawiania kolejnych punktów programu referatu.

Mgr Dawid Dudek (UAM), ,Wykluczenie społeczne Żydów w Cesarstwie Bizantyjskim w okresie od IV do XII wieku".

Trzecim, i ostatnim, referatem w pierwszej części konferencji była praca mgr. Dawida Dudka. W prezentacji omówiona została kwestia dyskryminacji wyznawców judaizmu w odniesieniu do artykułów prawnych wydawanych przez kolejnych chrześcijańskich władców cesarstwa. Autor tej pracy zauważa, że wiele ustaw zostawało przez kolejnych cesarzy powtarzanych bądź potwierdzanych, co każe zastanowić się nad tym, czy ówczesne społeczeństwo bizantyjskie faktycznie stosowało się do uregulowań prawnych wobec Żydów, czy też traktowało je z dystansem.

Po referacie mgr. Dawida Dudka, dyskusji i krótkiej przerwie rozpoczęła się druga część konferencji.

\section{Część druga - „Wykluczenie a niepelnosprawność”}

Mgr Julia Kisielewska-Meller (UAM), „Czy uszkodzenie słuchu warunkuje społeczną marginalizację".

Pierwsza w tej grupie wystąpień zabrała głos mgr Julia Kisielewska-Meller. W pracy omówiony został rys historyczny problemu oraz stereotypy, jakim podlegają ludzie dotknięci tym rodzajem niepełnosprawności. Autorka referatu stwierdziła, że osoby te często wyłączają się z życia społecznego na własne życzenie, zwróciła przy tym uwagę na błędną politykę państwa względem omawianej grupy społecznej. Ukazana została również ko- 
nieczność normalizacji, włączania, integracji czy inkluzji osób z tym problemem do społeczeństwa. Mgr Julia Kisielewska-Meller przedstawiła również wyniki badań własnych, przeprowadzonych metodą sondażu diagnostycznego w celu uzyskania informacji o jakości życia i uczestnictwie społecznym ludzi z uszkodzeniami słuchu. Badania te ujawniły, że osoby te nadal są traktowane $\mathrm{z}$ rezerwą.

Joanna Świerczek (UAM), „Osoby z niepełnosprawnością intelektualną - swoi czy obcy? Spostrzeganie społeczne osób z niepełnosprawnością intelektualną w przeszłości i czasach współczesnych"

Kolejny referat, przedstawiony przez Joannę Świerczek, dotyczył istoty postrzegania społecznego osób z niepełnosprawnością intelektualną bądź fizyczną. Studentka pedagogiki specjalnej omówiła to zagadnienie na przestrzeni wieków oraz zwróciła uwagę na to, w jaki sposób społeczeństwo te osoby traktuje współcześnie (omówienie pojęcia współczesnej marginalizacji). Pani Joanna Świerczek zwróciła również uwagę na ewolucję samego nazewnictwa osób niepełnosprawnych. Na podstawie przedstawionych danych konkludowała, że niepełnosprawni nadal są izolowani i stwierdziła, że mimo iż są częścią społeczeństwa, to nadal są dla niego „obcy”.

Łukasz Koperski (UAM), „Wykluczenie społeczne osób z niepełnosprawnością. Zagrożenia i szanse"

Ostatni referat w drugiej części konferencji został przygotowany i przedstawiony przez Łukasza Koperskiego. W tej pracy poruszony został temat wykluczenia społecznego osób z niepełnosprawnością fizyczną. Omówiona została tematyka getta, barier psychologicznych, prawnych, społecznych i architektonicznych, etykietowania, oraz relacji między niepełnosprawnymi a społeczeństwem. Pan Łukasz Koperski przedstawił również paradygmaty niepełnosprawności, dotyczące ich stereotypy i szanse na lepsze włączenie tej grupy do życia społecznego i kulturalnego. Warto podkreślić, że zostały w tej pracy omówione bariery architektoniczne, które autor pracy odszukał w miejscu swojego zamieszkania - w Poznaniu, oraz propozycje ich rozwiązania.

Po referacie nastąpiła chwila przerwy oraz burzliwa dyskusja.

\section{Część trzecia - „Wykluczenie społeczne a kultura”}

Mgr Konrad Nowak - Kluczyński (UAM), ,Subkultura graficiarzy - społeczna kontestacja czy próba nawiązania dialogu?"

Trzecią część konferencji rozpoczął referat mgr. Konrada Nowaka-Kluczyńskiego, który zajął się tematyką subkultury graficiarzy. Uczestnicy mieli okazję zapoznać się z rysem historycznym graffiti oraz pokaźną dokumentacją fotograficzną graffiti i muralów stworzoną przez autora. Jednym z podstawowych zagadnień prezentacji było pytanie, czy graffiti traktować należy jako sztukę czy jako wandalizm. Omówienia dokonano na trzech płaszczyznach - społecznej, psychologicznej i urbanistycznej. Mgr Konrad Nowak-Klu- 
czyński twierdzi, że jest to zarazem bunt, jak i próba dialogu, swoisty komunikat. Scharakteryzowany został też stereotypowy graficiarz. Zwrócono uwagę na to, w jaki sposób dostrzega się ludzi parających się tą formą wyrazu i w jaki sposób oni sami się opisują. Szczególnie istotne w tej prezentacji było przedstawienie graficiarzy w obiektywny sposób, bez tendencyjnego spojrzenia z jednej bądź drugiej „strony barykady”.

Mgr Tadeusz Mincer (UWr), ,Rola pojęcia rasy w kształtowaniu się wykluczenia społecznego".

W tym referacie mgr Tadeusz Mincer omówił pojęcie rasy i jej wpływ na kształtowanie się wykluczenia społecznego. W prezentacji została podjęta tematyka koncepcji rasowych, rasogenezy, funkcji rasy. Prelegent opisał, w jaki sposób pojmowanie tego pojęcia wpłynęło na politykę kolonialną. Proces wykluczenia społecznego oparty na pojęciu rasy leży poza możliwością kontroli danej jednostki, sama klasyfikacja rasowa jest negatywna.

Mgr Agnieszka Pogorzelska (UW) „Czy „obcy” musi być wrogiem? Przyczyny i przejawy wykluczenia osób narodowości innej niż Polska”.

W przedstawionej przez mgr Agnieszkę Pogorzelską pracy została scharakteryzowana wizja osoby „obcej” zarówno dla Polaków, jak i dla samej siebie. Według opinii autorki referatu słowo „obcy” często łączy się z mniejszością. Omówione zostało pojęcie dyskryminacji, pokrótce scharakteryzowane jej przejawy, szczególnie w odniesieniu do stereotypów. Zwrócono uwagę na brak polityki imigracyjnej w naszym kraju i potrzebę przeprowadzenia kampanii informacyjnych na rzecz uniknięcia problemów związanych $\mathrm{z}$ dyskryminacją. Autorka zastanawia się również nad pojęciami dyskryminacji, marginalizacji czy stygmatyzacji.

\section{Część czwarta - „Wykluczenie spoleczne a kultura, cz. II”}

Mgr Joanna Wicher (UAM), „Komunikacja z perspektywy różnych kultury, czyli czy obcy może stać się swój”.

Mgr Joanna Wicher zapoznała uczestników konferencji z zachowaniami typowymi w kulturze Państwa Środka. Ukazując, jak bardzo różnimy się od członków innych społeczności zwróciła uwagę na fakt, iż bardzo często stanie się „swoim” graniczy z niemożliwością, bądź wymaga dużego poświęcenia ze strony „obcego”. Słuchacze mieli okazję dowiedzieć się o symbolice charakterystycznej dla jednych, a tak odmiennej i dziwnej dla innych kultur. Prelegentka zaznaczyła też różny sposób podziału kultur oraz podzieliła się doświadczeniem nabytym podczas rocznego pobytu w Chinach.

Łukasz Pomiankiewicz (UAM), ,Starość w obliczu ponowoczesności, czyli dlaczego odeszliśmy od kultury postfiguratywnej?"

Autor referatu opisał wizję społeczeństwa kofiguratywnego. W swoim wystąpieniu prezentował dane zgromadzone podczas badań nad młodzieżą, ukazał zmiany w systemie 
wartości, celów oraz środków, za pomocą jakich młode pokolenia do nich dążą. Globalizacja powoduje ewolucję świata ku łatwiejszemu życiu. Autor przekonuje, że starość jest czymś we współczesnych realiach odrzucanym, odrzucanym w mediach na rzecz ideału wiecznej młodości. Starsi ludzie nie nadążają za zmieniającym się światem, więc wycofują się z życia społecznego, przez co stają się obcy, niezrozumiali, właściwie nieobecni. W konsekwencji marginalizacja starszych pokoleń jest coraz powszechniejsza.

Mgr Joanna Kuchta (UAM) „Piętno dewianta, stygmat normalsa - wykluczenie i stygmatyzacja w kulturze europejskiej”.

Prelegentka skupiła się nad pojęciami „piętno” i „normalność”, opisała podłoże historyczne zjawisk z nimi związanych oraz stereotypowe obrazy dewianta i normalsa. Zwróciła uwagę na podłoże psychologiczne ,piętna”, ukazując, że często łączy się ono z wadami charakteru posiadacza. Analizie poddane zostało $\mathrm{w}$ prezentacji również pojęcie „atrybutu” oraz to, że może on również stać się piętnem.

\section{Część piąta - „Wykluczenie spoleczne a kultura, cz. V”}

Mgr Katarzyna Kołodziejczyk (UŚ), „Model bohatera greenowskiego - poczucie inności”.

W tej prezentacji magister literaturoznawstwa przedstawiła model bohatera greenowskiego. Zapoznała uczestników konferencji z rysem biograficznym Juliana Green'a oraz opisała, jak jego życie wpłynęło na twórczość literacką. Bohater greenowski jest człowiekiem, który czuje się inny, wyobcowany, niezrozumiany i nie próbuje z tym walczyć.

Bartosz Górski (UAM), „Cenzura prewencyjna PRL jako próba dyskryminacji polskich niezależnych środowisk muzycznych”.

Wystąpienie Bartosza Górskiego traktowało o odrzuceniu przez system władzy PRL-u niezależnych środowisk muzycznych. Opisywało rodzaje cenzury, historię walki z nią oraz anegdoty związane z omijaniem jej sieci. Uczestnicy spotkania dowiedzieli się o historii piosenki studenckiej, o fakcie, że w ówczesnych realiach mogła stać się prawdziwą bronią polityczną. Autor pracy pokazuje, iż władza nie miała skrupułów, by marginalizować nieuległych wykonawców.

Mikołaj Fryza (UAM), „Wykluczenie społeczne mniejszości narodowych na przykładzie Romów Polskich".

Ostatnią prezentacją przestawioną na omawianej konferencji była praca Mikołaja Fryza, traktująca o wykluczeniu społecznym mniejszości narodowych i etnicznych na przykładzie Romów. Omówiona w niej została tematyka kwalifikowania mniejszości, stereotypów, jakimi są określane oraz podejściem instytucji państwa do tej problematyki. Autor zwrócił uwagę na różny sposób traktowania Romów w poszczególnych częściach Polski, opisał próby zasymilowania przez streetworking, problemy natury socjalnej oraz specyficzne, związane z ich kulturą podejście do edukacji. 


\title{
Zakończenie konferencji
}

Podsumowania referatów wygłosił dr Krzysztof Ratajczak. Opisał on dokonania uczestników konferencji. Zauważył, że prawdziwą istotą tego spotkania była dyskusja, omawianie prezentacji przez ludzi specjalizujących się w innych dziedzinach nauki. Aktualnie dużo mówi się o konieczności prowadzenia interdyscyplinarnych prac, jednak niemożliwe wydaje się przeprowadzanie tego typu badań przez jednego tylko naukowca, gdyż nie jest on w stanie samodzielnie opracować danego tematu z perspektywy wielu dziedzin nauki jednocześnie. Właśnie dlatego, konferencje takie jak ,Wykluczenie społeczne wczoraj i dziś” mają dużą wartość. W dyskusjach po wysłuchaniu kolejnych referatów udział brali specjaliści z wielu dziedzin, i właśnie jednoczesne analizowanie problemu przez tak różnorodny zespół jest sposobem prowadzenia badań interdyscyplinarnych.

\author{
Dobrostaw Rola, \\ student socjoterapii i promocji zdrowia, \\ WSE, Uniwersytet im. Adama Mickiewicza w Poznaniu
}

\section{Sprawozdanie z Seminarium Naukowego w Obrzycku, 28-29 czerwca 2011 r.}

W dniach 28-29 czerwca 2010 r. w Domu Pracy Twórczej i Wypoczynku w Obrzycku, odbyło się Seminarium Naukowe, zorganizowane przez Zakład Historii Wychowania Uniwersytetu im. Adama Mickiewicza w Poznaniu. Uczestniczyli w nim nie tylko osoby związane bezpośrednio z Zakładem, ale również zaproszeni goście, reprezentujący środowisko naukowe historyków wychowania. Uczestnicy seminarium tym razem dyskutowali na temat ikonografii w badaniach historyczno-pedagogicznych.

Zebranych gości przywitała prof. Dorota Żołądź-Strzelczyk, przedstawiając na wstępie niedawno promowanych w Zakładzie Historii Wychowania UAM doktorów: Michała Nowickiego, Mikołaja Brenka, Tomasza Fetzkiego oraz Annę Knocińską. Następnie podany został program seminarium. Kierowania obradami podjął się prof. Wiesław Jamrożek, który zaproponował, aby wszyscy zebrani dokonali autoprezentacji, z uwzględnieniem zainteresowań badawczych.

Pierwsza referat wygłosiła prof. dr hab. Dorota Żołądź-Strzelczyk z Uniwersytetu im. Adama Mickiewicza w Poznaniu. Jego tematem była ikonografia w badaniach historyczno-pedagogicznych. We wprowadzeniu referentka przedstawiła zwięzły zarys wykorzystywania źródeł ikonograficznych przez historyków sztuki oraz archeologów. Następnie podkreśliła wartość tego rodzaju źródeł dla historyków wychowania - interesująca dla nich jest przede wszystkim warstwa treściowa, jak zostało dowiedzione. W dalszej części referatu dokonana została typologizacja źródłowych materiałów ikonograficznych, z pre- 